\title{
Transition of Human Resources from PT. Sindu Utama Bahari to PT. Agung Line due to Acquisition Process
}

\author{
Redywan James Purba, Charles Bohlen Purba \\ Master of Management, Mercu Buana University, Jakarta, Indonesia
}

\begin{abstract}
This study aims to explore and analyze the transition of human resources from PT. Sindu Utama Bahari to PT. Agung Line due to acquisition process. Research data is from the semi-structured interview result to the extended crew. The sampling method used was purposive random sampling. Sample criteria are senior officers and middle officers positions with an adult age category. The method of analysis used in this study is the SWOT analysis method with IFES-EFES matrix and also interview result coding derivative to find the framework of transition process. The results of the analysis show that the company has strong capital through Competence, Commitment, Work Discipline and Work Culture of the crew who were developed previously. This is necessary to compete with threats and opportunities.
\end{abstract}

Keywords:- Transition of human resources, Competence, Commitment, Work Discipline, Work Culture, Crew.

\section{INTRODUCTION}

The acquisition process of a company is something that often happens in Indonesia. Acquisition or acquisition of ownership of shares / assets of companies by other companies is usually done so that the company is able to achieve growth faster than building new business units.

The decision to transfer Human Resources (HR) usually depends on the company strategy that makes the acquisition. Law No.13 of 2003 concerning manpower regulates the status of workers after acquisition, whereWorkers' rights are the responsibility of the new employer, unless specified otherwise in the transfer agreement.

PT. Sindu Utama Bahari, a crossing service company in Bali and Lombok. Beginning in 2017, Agung Concern Group (ACO) with its shipping subsidiary PT. Agung Line acquired PT. Sindu Utama Bahari. The process of transitioning HR has its own challenges with various considerations.

ACO Values are the main guidelines in the transition process. Integrity, integrity of job competencies. Courage, the courage to change behavior to reflect work discipline. Respect, Work Culture between employees for mutual respect. Collaboration, working together to achieve goals with good work commitment.

\section{LITERATURE REVIEW}

\section{$>$ Competence}

According to Spencer \& Spencer (2007) competence is an individual's basic characteristics related to effective and / or causal or causal relationships in work situations.

An employee can be said to meet competence if it meets the elements:

- Knowledge (knowledge). Having knowledge gained from formal learning and / or training or courses related to the field of work being handled.

- Expertise (skill). Having expertise in the field of work being handled and able to handle it in detail. In addition to experts, he must have the ability (ability) to solve problems and solve things quickly and efficiently

- Behavior (attitude). Uphold organizational ethics and have a friendly and polite attitude in acting. This attitude cannot be separated from one's duties in carrying out work properly and this is an important element for service businesses / services and even has an influence on companies / organizations.

$>$ Work Discipline

According to Terry (2011: 218), work discipline consists of;

- Self Inposed Dicipline, namely discipline arising from oneself on the basis of willingness, awareness and not arising on the basis of coercion. This discipline arises because a person feels fulfilled his needs and has become part of the organization so that employees are moved to realize and voluntarily comply with all applicable regulations.

- Dicipline Command, namely discipline arising from coercion, order and punishment and power. This discipline does not arise because of feelings of sincerity and self-awareness but because there are threats from others.

Work discipline aims to improve efficiency and to the maximum extent possible prevent time and energy waste and other damage.

\section{$>$ Work Commitment}

Work commitment is a condition of an employee who sides with a particular organization, as well as his goals and desires to maintain his membership in the organization (Robbins and Judge, 2008). 
The focus of work commitment lies in the degree to which employees want to believe fully, are willing to accept company goals and are willing to stay and not leave the company for a long time.

\section{Work Culture}

Work culture is built and maintained through the philosophy of the founder or leader. This work culture is strongly influenced by the criteria used in employing employees. But slowly these values will automatically be selected to make adjustments to changes that will eventually emerge the desired work culture.

Collins and Porras said that the work unit or organization would be able to achieve the highest success if it had; 1) Great goals and targets; 2) Firmness but flexible at the same time; 3) Work culture that is lived fanatically; 4) Creative innovation power; 5) Human resource development system (HR) from within; 6) Quality orientation to perfection; and 7) Ability to continuously learn and change peacefully.

\section{METHODOLOGY}

\section{Research Object}

Employees who are the object of research are the crew in the position of Officer and Top Four and middle adulthood (ages 18-25 years). The characteristics of the length of work at least 2 years and is not a new crew that was recruited after the acquisition of the management of Sindu Utama Bahari. The sample was selected by using purposive random sampling technique.

\section{Research methods}

The approach used in this research is a qualitative approach with descriptive methods. Descriptive qualitative research methods aim to express events or facts with the right interpretation (Whitney, 1960).

So, this research is designed to find out about the process of transitioning Human Resources from PT. Sindu Utama Bahari to PT. Agung Line qualitatively.

\section{$>$ Data collection technique}

Data collection techniques using interview techniques with a list of semi-structured questions whose results will be recorded verbatim and observation. The results of observations by researchers are detailed in Strength Weakness - Opportunity - Threat (SWOT).

\section{$>$ Analysis Techniques}

Data analysis was performed using a qualitative approach with a process that involved data reduction, data display, data analysis, verification and conclusion that continued to interact throughout the study. As a comparison, researchers use the methodanalysis of Strength - Weakness - Opportunity - Threat (SWOT)with Internal Factor Analysis Summary (IFAS) and External Factor Analysis Summary (EFAS) specifications.

\section{RESULT}

Based on Axial Cooding made in this study, there are 4 steps undertaken by PT. Agung Line in carrying out the HR transition process as follows;

- Conducting the Agung Line Company Socialization Program to the crew.

- Perform good procedures that exist and leave bad habits.

- Carry out the Administrative Expert function.

- Running the Strategic Employee Champions program.

Through the results of the SWOT analysis with IFAS and EFAS factors we find the following;

- The value of Internal factors, namely the strength factor is 2,19231 points and the weakness factor is 1,19231 points. Thus, the basic policy is the value of strength (strength).

- The value of External factors, namely the opportunity factor (Oportunity) is 2,18750 points and the threat factor (Threat) is 0.56250 . Thus, the basis of policy is opportunity value.

By entering the total IFAS data of 3.38462 and EFAS of 2.75000 into the Internal External Matrix (IE), it will be found that the company is in Stability which tends to lead to Growth, which is a strategy that has potential and some strategic considerations in the performance development plan without having to change the strategy has been applied.

In principle, this strategy is growth that emphasizes the point of increasing employee performance with company functions because it seeks to increase efficiency in all fields in order to improve performance and profits.



Fig 1:- Results of External Internal Matrices (IE)

\section{$>$ Cartecius Diagram of SWOT Analysis}

The total points value of each factor can be specified Strength 2.19231, Weakness 1.19231, Opportunity 2.12500 and Treath 0.62500 , then the difference between the total points Strength and Weakness factors (+) 1.00000. while the difference in the total points factor Opportunity and Treath (+) 1.50000 . 


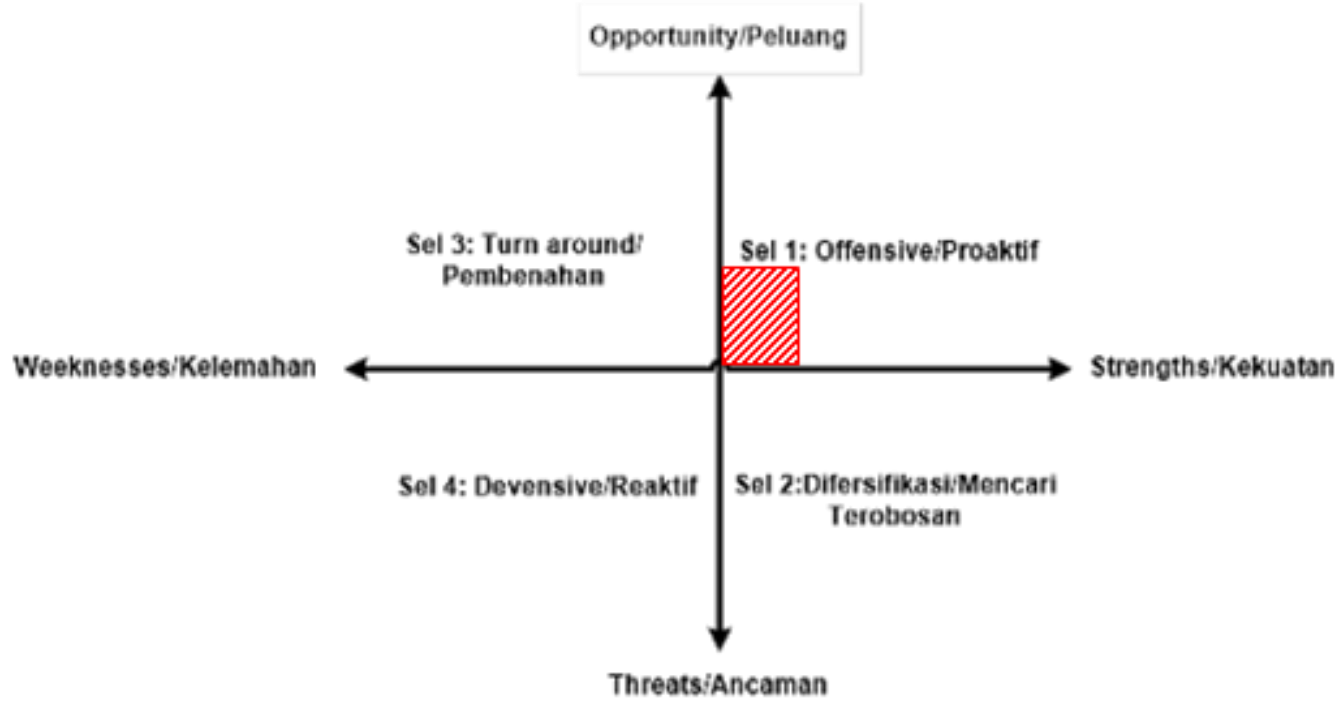

This shows that the company is in the growth quadrant where the quadrant is a very favorable situation. The company has opportunities and strengths so that they can take advantage of existing opportunities. The strategy that must be applied in this condition is to support an aggressive growth policy. This strategy signifies a company that is strong and able to develop by taking the opportunity or opportunities that exist to achieve maximum turnover.

\section{CONCLUSION}

Based on the existing explanations, it can be concluded as follows:

$>$ The process of transitioning Human Resources (HR) from PT. Sindu Utama Bahari to PT. Agung Line due to the acquisition process is done by maintaining good values and increasing the effectiveness of the values that have been run before.

> Competence, work discipline, work commitment and work culture have increased.

\section{REFERENCES}

[1]. Dessler, Gary (2010). Human Resource Management (tenth edition). Jakarta: PT Index.

[2]. Dessler, Gary \& Diana Angelica (2015). Human Resource Management (fourteenth edition). Jakarta: Salemba Empat.

[3]. Hasibuan, Malayu SP (2014). Management - Basics, Understanding and Problems. Jakarta: Earth Literacy.

[4]. Hasibuan, Malayu SP (2014). Human Resource Management. Jakarta: Earth Literacy.

[5]. Kusumaputri, Erika Setyanti (2015). Commitment to Organizational Change: Organizational Change in Islamic and Psychological Perspectives. Yogyakarta: Deepublish.

[6]. Mangkunegara, Anwar P. (2015). Organizational Behavior and Culture. Bandung: PT. Refika Aditama.

[7]. Mangkunegara, Anwar P. (2014). Corporate Human Resource Management. Bandung: Teen Rosdakarya.
[8]. Nawawi, Ismail (2013). Leadership and Performance organizational culture. Jakarta: PT. Fajar Iterpratama Mandiri.

[9]. Ndraha, Taliziduhu (2015). Theory of Organizational Culture, First Matter, Jakarta PT. Rineka Cipta.

[10]. Palan, R (2012). Competency Management, Techniques for Implementing Competency-based HR Management to Improve Organizational Competitiveness. Jakarta: PPM Publisher.

[11]. Prawirosentono, Suyadi (2010). Human Resource Management: Employee Performance Policy. Yogyakarta: BPFE.

[12]. Purnadi, Pungky (2017). Competencies Based Management, From Design to Implement and Continuous Improvement - Paper Presentation. Kuala Lumpur: Not published.

[13]. Rivai, Veithzal and Ella Djauhari S. (2015). Human Resource Management for Companies. Jakarta: Rajawali Press.

[14]. Rivai, Veithzal (2014). Human Resource Management for Companies From Theory to Practice. Bandung: Rajagrafindo Persada.

[15]. Robbins, P. Stephen and Timothy A. Judge (2008). Organizational behavior. Issue 12. Volume 1, Interpreting Diana Angelica et al. Jakarta: Salemba Empat.

[16]. Schein, Edgar H. Honal Culture and Leadership, Fifth Edition. New Jersey: John Wiley \& Sons, Inc.

[17]. Sinamo, Jansen H. (2012). Ethos 21: Professional Work Ethics in the Global Digital Era. Jakarta: Institut Darma Mahardika.

[18]. Spencer, Lyle \& Signe M. Spencer (2017). Competence at Work, Models for Superior Performance, Canada: John Wiley \& Sons, Inc.

[19]. Sudarmanto (2019). HR Competency Performance and Development, Yogyakarta: Student Library.

[20]. Sugiyono (2010). Educational Research Methods, Quantitative Approaches, Qualitative and R\&D, Bandung: ALFABETA. 
[21]. Sutrisno, Edy (2016). Human Resource Management. Jakarta: Kencana.

[22]. Tika, Moh. Pabundu (2018). Organizational Culture and Improvement of Company Performance. Jakarta: Earth Literacy.

[23]. Terry, George R. (2011). Fundamentals of management. Jakarta: Earth Literacy.

[24]. Triguno 2014. Work Culture. Jakarta: PT. Golden Trayon Press.

[25]. Umam, Khaerul (2010). Organizational behavior. Bandung: Loyal Reader.

[26]. (2018). The Concern Agung Culture Book. Jakarta: Not published. 